\title{
Turmeric and Fenugreek - Herbal Agents to Alleviate Sickle Cell Disease
}

\author{
Rawda Aljadar ${ }^{1}$, Mohammed Yunus ${ }^{2 *}$, Amr Zaher ${ }^{3}$ \\ ${ }^{1}$ Hematopathology Specialist, Dammam Regional Laboratory and Blood Bank, Dammam, Saudi Arabia \\ ${ }^{2}$ Associate Professor and Consultant Hematopathologist, King Fahd Hospital of the University, Imam Abdulrahman Bin Faisal University, Dammam, \\ Saudi Arabia. \\ ${ }^{3}$ Assistance Professor and Consultant Hematopathologist, King Fahd Hospital of the University, Imam Abdulrahman Bin Faisal University, \\ Dammam, Saudi Arabia
}

*Corresponding author: Mohammed Yunus, Hematopathology Laboratory, King Fahd Hospital of the University, Al-Aqrabiya, Al-Khobar Saudi Arabia.

Received date: April 21, 2021; Accepted date: June 19, 2021 ; Published date: August 20, 2021

Citation: Aljadar R., Yunus Md., Zaher A., (2021) Turmeric and Fenugreek - Herbal Agents to Alleviate Sickle Cell Disease. J, Clinical Medical Reviews and Reports. 3(7); DOI:10.31579/2690-8794/082

Copyright: (c) 2021, Mohammed Yunus, This is an open access article distributed under the Creative Commons Attribution License, which permits unrestricted use, distribution, and reproduction in any medium, provided the original work is properly cited.

\begin{abstract}
Introduction: Sickle cell disease (SCD) is a genetic disorder with autosomal recessive inheritance causing abnormal hemoglobin. It is an important medical problem globally as well as in our community at Eastern province of Saudi Arabia. It accounts for large numbers of morbidity and to a lesser extent mortality. Several natural plant products over the world, which were known in some communities and their traditional healers, were studied and found to have properties in improving SCD manifestation. This research was planned to explore if any plant product under our study could prove being an effective anti-sickling agent for therapeutic use in SCD management.
\end{abstract}

Objectives: Studying the effects of some plants on sickled RBCs as well as comparing between efficacies of these different plants.

Material and Methods: The 49 fresh whole blood samples, extracted through venipuncture in EDTA tubes, were collected from known SCD patients whose homozygosity were confirmed by hemoglobin electrophoresis. These patients were not on recent blood transfusion or hydroxyurea, and aged 14 years or above of both sexes on clinical follow up. The dried rhizomes of turmeric (curcuma longa) powder and dried seeds flour of fenugreek (trigonella foenum-graecum) were used to evaluate the reversal type of anti-sickling activity on RBCs.

Results: Out of 49 blood samples, 28 (57.1\%) samples were from males and 21 (42.9\%) samples from females. The average $( \pm$ SD) age of the cases was $28.2( \pm 9.97)$ years with range $14-60$ years. Significant anti-sickling activity was found using Turmeric rhizomes extract treatment with $66.81 \%$ reversal effect, and $61.28 \%$ anti-sickling action when fenugreek seeds extract was used.

Conclusion: The findings of this study suggest that turmeric (C. longa) rhizome extract and fenugreek seed extract could have promising anti-sickling properties for SCD treatment.

Keyword: sickle cell disease; genetic disorder; homozygosity

\section{Introduction}

Sickle cell disease (SCD) is an inherited red blood cell (RBC) disorder, caused by missense mutation of single base pair change (GAG $\rightarrow$ GTG; adenine to thymine) in hemoglobin beta (HBB) gene leading to single amino acid substitution of valine for glutamic acid at the sixth position of beta-globin chain, resulting in hemoglobin $\mathrm{S}(\mathrm{HbS})$ production [1]. It could be homozygous (HbSS) or compound heterozygous like HbSC or
HbS-beta thalassemia. Under hypoxic condition, HbS polymerizes resulting in RBC rigidity and distortion in morphology (sickled RBCs), that cause impaired microcirculation and extravascular hemolysis. The resultant clinical manifestations includes pain, vaso-occlusive crisis, splenic sequestration, acute chest syndrome, hemolytic anemia, and stroke. These manifestations are outcome of the pathophysiological processes that include vascular-endothelial dysfunction, oxidative and 
reperfusion injury, increased neutrophil adhesiveness, platelet activation, inflammation, and hypercoagulability $[2,3]$.

Our region (Eastern Province of Saudi Arabia) has the fifth major haplotype - the Arab-Indian type - (also called the Asian or Saudi haplotype). This has milder disease phenotype due to some genetic factors such as high levels of fetal hemoglobin and alpha thalassemia state that are commonly observed in the region [4].

The HbS polymerization leading to sickling has been mainstay of the pathophysiology of SCD. Hydroxyurea, a fetal hemoglobin inducing agent has been shown to decrease the number and severity of sickle cell crises [1-3, 5]. It has been approved by FDA (1998) and European Medicines Agency (2007). The Agency for Healthcare Research and Quality (AHRQ) in 2008 and the National Institutes of Health Consensus Development Conference has also recognized it [5, 7]. Various antisickling agents have been investigated and confirmed to have ameliorative properties [7].

Despite its wide acceptance, hydroxyurea is moderately toxic drug especially when administered for long-term duration [8]. In search of inexpensive but effective and readily available therapy, several investigations have been conducted on indigenous plant materials and their products. Among the commonly used plants in Nigeria and other African nations for management of many illnesses including sickle cell disease are leaves of Terminalia catappa (Indian almond) [9, 10] and Carica papaya (papaya). ${ }^{11}$ Others include Cajanus cajan (pigeon pea) seeds, [12] Adansonia digitata (baobab or upside-down tree) bark, Khaya senegalensis (African mahogany) leaves, and root of Fagara xanthoxyloides (Senegal prickly-ash or artar root) [13].

Anthocyanins extract of Trema orientalis was analyzed for antisickling/anti-hemolysis effect in vitro in Congo. It has been suggested that its effect was by interfering with intracellular polymerization of $\mathrm{HbS}$ or by scavenging the RBC free radicals [14]. The anti-sickling effect of ginger dried rhizomes has been in-vitro experimented [15].

The aim of this study is to explore if Trigonella foenum graecum or Fenugreek and Curcuma longa rhizomes could be effective as antisickling agents by reversing the already sickled RBC in order to alleviate sickle cell disease morbidity and to reduce the associated mortality.

\section{Material and method}

Dried rhizomes of turmeric (curcuma longa) powder and dried seeds of fenugreek (trigonella foenum-graecum) flour were used for the study. Individually preparing 5 grams of each plant material in covered glass flasks, soaked in $200 \mathrm{ml}$ normal saline $(0.9 \% \mathrm{NaCl})$ for $25 \mathrm{mg} / \mathrm{ml}$ concentration in room temperature for 24 hours. These solutions were filtered and kept in $2-6{ }^{\circ} \mathrm{C}$ (refrigeration). The required amounts were taken and brought at room temperature for use at the time of procedure. $2 \%$ sodium hydrosulfite has been used as sickling agent.

After taking institutional (IAU/KFHU) approval, 49 fresh whole blood samples through venipuncture in EDTA tubes, were collected from known SCD patients whose homozygosity were initially screened by sickling test and confirmed by hemoglobin electrophoresis. The patients were sample part of the routine follow up CBC analysis. These patients were not on recent blood transfusion or hydroxyurea, and aged 14 years or above of both sexes on clinical follow up. The dehydration or over hydration have been avoided in the selection of cases. The experiment was performed to evaluate the reversal anti-sickling activity of the plants under study.

\section{Experimental procedure}

In this in vitro experiment for each blood sample, $0.1 \mathrm{ml}$ of $2 \%$ Sodium Hydrosulfite sickling agent solution was added in test tube to $0.2 \mathrm{ml}$ whole blood. This was gently mixed and kept for standing for 10 minutes at room temperature. The peripheral blood $(\mathrm{PB})$ smear was made from the mixture (pre). After which, $0.1 \mathrm{ml}$ of this mixture was added to $0.1 \mathrm{ml}$ of each test containing plant materials (curcuma longa and fenugreek solutions) in separate test tubes. It was mixed thoroughly and kept at 37 ${ }^{\circ} \mathrm{C}$ in thermostatic dry incubator for 30 minutes. Subsequently, the PB smears were made (post). Both these (pre \& post) PB smears were examined under x100 high power with oil emersion light microscope for estimating the percentage of sickled and non-sickled RBCs for antisickling assay (reversal effect). The following formula was used:

Percentage of sickled cells $=$ number of sickled cells counted $/$ number of total RBCs counted $\mathrm{x} 100$

\section{Data Analysis}

All data were analyzed by using IBM SPSS.20.0. Frequency and percentage was calculated for gender. Mean and SD was calculated for all quantitative measures. Paired t-test was used to compare the means of sickled and non-sickled cells before and after plant mixture while independent sample t-test was used to compare sickled and non-sickled cells between two methods. Probability ( $p$-value) of $<0.05$ was considered as statistically significant.

\section{Results}

A total of 49 known $\mathrm{Hb}$ SS sickle cell disease patients were included in this study. Majority $28(57.1 \%)$ of cases were males while $21(42.9 \%)$ were females $(\mathrm{M}: \mathrm{F}=1: 0.75)$. Figure 1

Average $( \pm \mathrm{SD})$ age of cases was $28.2( \pm 9.97)$ years with range of $14-60$ years. Majority of cases had age between $20-30$ years. Figure 2

Figure 3 shows anti-sickling effect of two methods as compared with pretreatment (negative control). The upper and lower lines of the boxes indicate the upper and lower quartiles of the data and the middle bold lines indicate the median values. The whiskers indicate the minimum and maximum values.

The average percentage of sickled RBC before adding the extracts was $23.5 \pm 4.2 \%$ then after adding the fenugreek seeds extract the mean percentage of sickled cells was decreased to $9.1 \pm 3.3$ ( $\mathrm{p}$ value $<0.001$ ) while after adding turmeric rhizomes extract, the mean percentage of sickled cells was decreased to $7.8 \pm 3.5$ ( $\mathrm{p}$ value $<0.001$ ). Accordingly, Turmeric root extract gave better results when compared with fenugreek seed extract $(\mathrm{p}$-value $=0.025)$. Table 1

Table 2 shows the percentage of normal RBC with pretreatment estimation of $76.6 \%$ while with Turmeric rhizomes extract showed $92.2 \%$ ( $\mathrm{p}$ value $<0.001$ ) of red cells and compared with fenugreek seeds extract, which gave $90.9 \%$ ( $p$ value $<0.001$ ). The $p$-value $=0.025$ was found between the two products.

Table 3 shows that in relation to the pretreated sickled RBC, $61.28 \%$ of cells become corrected and reversed into non-sickled by applying fenugreek seeds extract with $38.72 \%$ remained irreversibly sickled. However, when turmeric rhizomes extract was used, $66.81 \%$ or around two thirds of sickled cells were normalized while $33.19 \%$ stayed uncorrected. Turmeric to fenugreek effect ratio of 1.09:1. (Figure 4) 


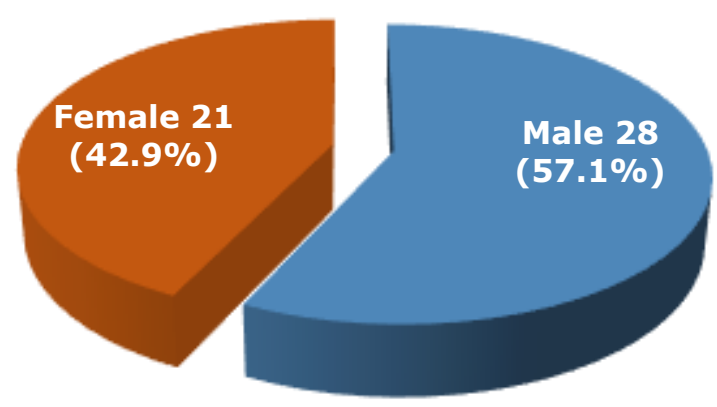

Figure 1: Gender Distribution (Male: Female =1:0.75); $N=49$

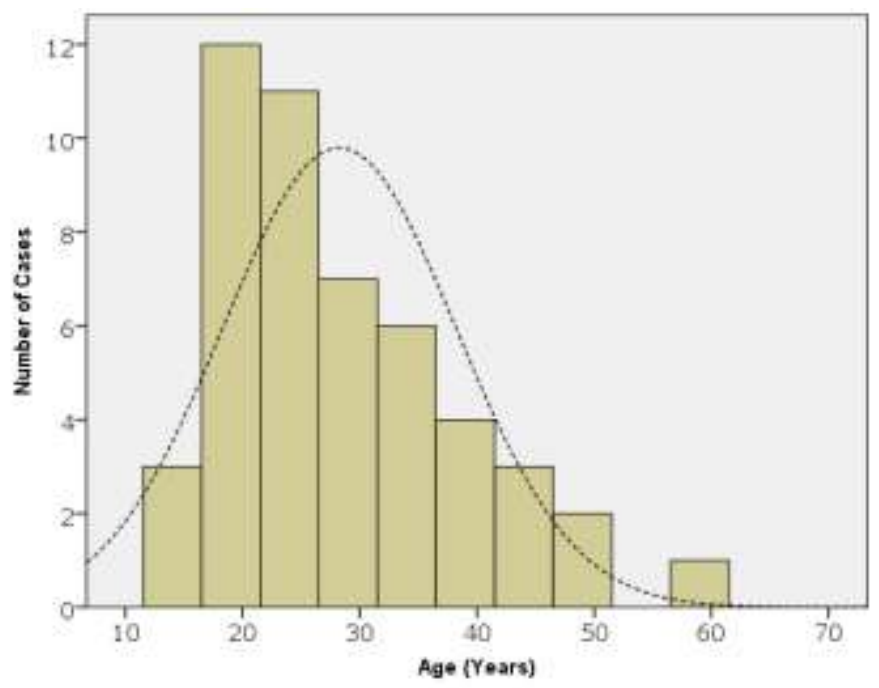

Mean \pm SD $=28.2 \pm 9.97$ Years

Min - Max $=14-60$ Years

Figure 2. Age distribution of all cases $(N=49)$

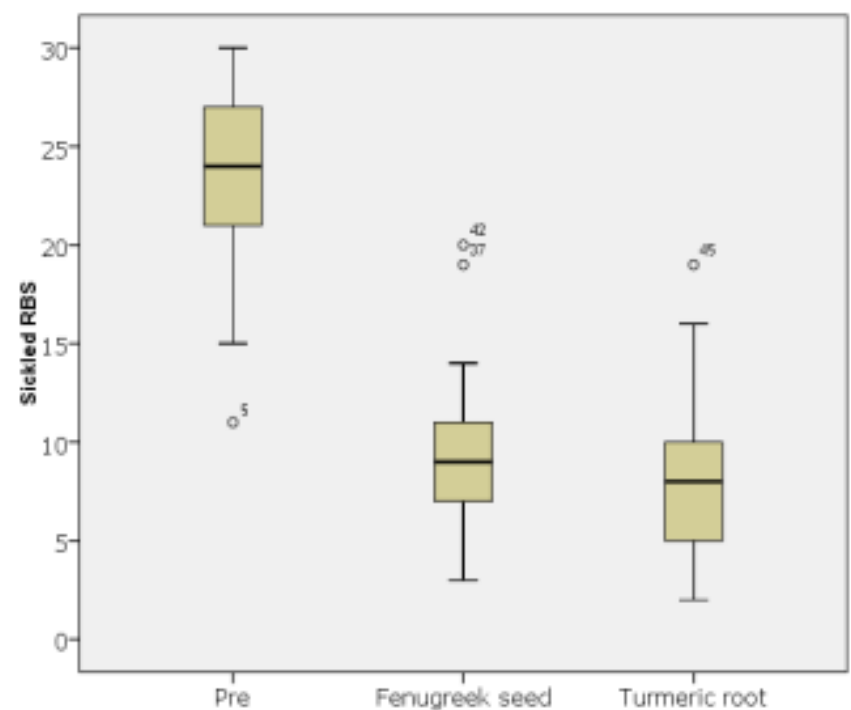

The upper and lower lines of the boxes indicate the upper and lower quartiles of the data and the middle bold lines indicate the median values. The whiskers indicate the minimum and maximum values. 


\section{Fenugreek Seeds Anti-sickling Effect}

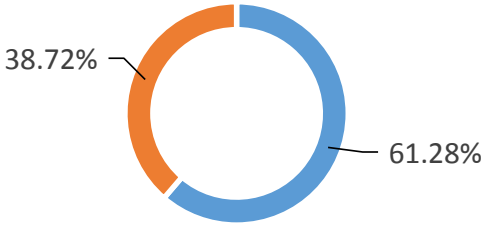

- Normalized Sickled RBC - Uncorrected Sickled RBC

\section{Turmeric Rhizomes Anti-sickling Effect}

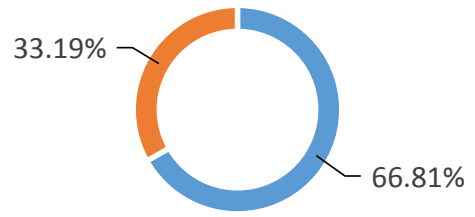

- Normalised Sickled RBC $\quad$ - Uncorrected Sickled RBC

Figure 4: Doughnut Chart for comparison of Anti- sickling Effects of both solutions with pre treatment

* By Independent Sample t-test

Table 1: Comparison of sickled RBC in anti-sickling analysis of two methods with pre-treatment $(N=49)$

\begin{tabular}{|l|c|c|c|}
\hline & \multirow{2}{*}{$\begin{array}{c}\text { Mean } \pm \text { SD } \\
\text { Non-sickled RBC }\end{array}$} & \multicolumn{2}{|c|}{ P value by Paired T-test } \\
& $76.6 \pm 4.2$ & Pre Vs Fenugreek Seed & Pre Vs Turmeric Root \\
\hline Pretreatment & $90.9 \pm 3.3$ & $<0.001$ & $<0.001$ \\
\hline Fenugreek Seed & $92.2 \pm 3.5$ & & \\
\hline Turmeric Root & \multicolumn{2}{|c|}{0.025} & \\
\hline $\begin{array}{l}\text { (Fenugreek Vs } \\
\text { Turmeric) }\end{array}$ & \multicolumn{2}{|c|}{} \\
\hline
\end{tabular}

* By Independent Sample t-test

Table 2: Comparison of normal RBC in anti-sickling analysis of two methods with pre-treatment $(N=49)$

\begin{tabular}{|l|l|l|}
\hline$\%$ & Fenugreek Seeds anti-sickling effect & Turmeric Rhizomes anti-sickling effect \\
\hline Normalized Sickled RBC & 61.28 & 66.81 \\
\hline Uncorrected Sickled RBC & 38.72 & 33.19 \\
\hline Total & 100 & 100 \\
\hline
\end{tabular}

Table 3: comparison of anti-sickling effects of two

\section{Discussion}

Sickle cell disease is an inherited autosomal recessive disorder which is common in Sub-Saharan Africa, the Mediterranean areas, Arabian Peninsula, South Asia, and Southeast Asia. According to the World Health Organization, African population has the highest prevalence of the disease that ranges from $10-40 \%$ and in countries where the trait prevalence is over $20 \%$, the disease affects about $2 \%$ of the people [16]. Generally, it is estimated that $7 \%$ of the overall populations in the world are carriers of hemoglobinopathies [17,21].

The phytotherapy is recently used as an alternative medicine that can provide relief for SCD patients. The review of the literature indicated that various plants have been tested and shown to have anti-sickling potential 
effects, of which was Curcuma longa $[18,21]$. It was reported that the extracts of rhizomes of $\mathrm{C}$. longa have several pharmacological effects such as anti-inflammatory, anti-cancer, healing, cholesterol-lowering, hypoglycemic, anti-Alzheimer, anti-plasmodial, antioxidant, anti-venom, antibacterial, antifungal, antipyretic, and analgesic properties. It also has protective potential against diabetic retinopathy and other pathologies [18].

In this study, 49 fresh whole blood samples of confirmed sickle cell disease patients were collected. Majority $57.1 \%$ of cases were males (M: $\mathrm{F}=1: 0.75)$. Average $( \pm \mathrm{SD})$ age of cases was $28.2( \pm 9.97)$ years. Average percentage of sickled RBC before adding the extracts was $23.5 \pm 4.2 \%$ and, after adding Fenugreek seed extract the mean percentage of sickled cells was significantly decreased to $9.1 \pm 3.3$ (p value $<0.001$ ), and when adding Turmeric rhizome extract the mean percentage of sickled RBC was significantly decreased to $7.8 \pm 3.5$ ( $\mathrm{p}$ value $<0.001$ ). Between the two products, Turmeric rhizome extract had shown to be more active when compared with Fenugreek seed extract but the difference is not significant ( $p$-value $=0.025$ ). Turmeric rhizome extract was found to be effective agent with $66.81 \%$ anti-sickling activity and Fenugreek seed extract with $61.28 \%$ reversal anti-sickling effect.

The anti-sickling potential of extracts from different organs (rhizomes, roots, leaves, petals, and sepals) of Curcuma longa was described by the researchers [18]. The most recent study of this plant for SCD management has also reported that the anti-sickling potential of different parts of Curcuma longa. Their results revealed that extracts of Curcuma longa leaves, which are rich in anthocyanin, have a prominent anti-sickling activity [22]. According to several studies, the anti-sickling effect of plants is mainly due to the presence of anthocyanins and organic acids. Anthocyanins interact with $\mathrm{HbS}$, competing with the polymerization process and preventing RBC sickling [20,21]. The total aqueous extracts as well as the total methanol extracts of different organs of Curcuma longa have shown considerable anti-sickling properties [18]. Several studies found that extracts of Curcuma longa, including from the flowers, contain large amounts of total polyphenols which have characteristic antioxidant and scavenging properties [23-25].

\section{Limitation and suggestions}

Although this study was limited with time constrain, manual-steps process but it was good to establish such a study in Saudi Arabia where SCD affects many patients particularly in Eastern and South Western areas.

Further studies are recommended to identify the specific compounds of different parts of these herbs that pharmacologically cause their therapeutic activity. Moreover, dose and additive effects as well as druginteractions are suggested in future evaluation. In addition, in vivo researches with more objective, practical and validated advanced techniques are recommended, also, to correlate all of that with the disease phenotypes in multicenter analysis on larger cohort groups to provide more understanding of the beneficial effects of such plant products.

\section{Conclusion}

The finding of this study suggests that Turmeric (Curcuma longa) rhizome extract and Fenugreek seed extract were shown to have antisickling properties for SCD management. Further studies are required to confirm and explain the roles of plant products in-vivo.

\section{Acknowledgements}

I would like to thank those who kindly provide generous support, starting by my supervisor Associate Professor Mohammed Yunus for his scientific guidance and sincere criticism all the time. I also thank Professor Layla Bashawri, Professor Yasser Osman and Assistant Professor Amr Zaher for their role as advisory committee members.
Also, special regards and appreciation to KFHU hematology laboratory staff as well as a lot of thanks to my colleagues and patients.

\section{Declaration of conflict of interest}

All authors declare that there is no conflict of interest.

\section{Funding}

No funding was provided.

\section{Ethical approval}

Institutional Review Board (IRB) approval from Imam Abdulrahman Bin Faisal University was obtained before starting the research project.

\section{References}

1. Carden MA, Little J. (2019) Emerging disease-modifying therapies for sickle cell disease. Haematologica. 104(9):17101719.

2. Salinas Cisneros G, Thein SL. (2020) Recent Advances in the Treatment of Sickle Cell Disease. Front Physiol. 11:435.

3. Frédéric B. Piel, Martin H. Steinberg, and David C. (2017) Rees. Sickle Cell Disease. N Engl J Med. 376:1561-73.

4. Jastaniah W. (2011) Epidemiology of sickle cell disease in Saudi Arabia. Ann Saudi Med. 31(3):289-293.

5. Cokic V, Smith R, Beleslin-Cokic B, Njoroge J, Miller J, Gladwin M, Schechter A. (2003) Hydroxyurea induces fetal hemoglobin by the nitric oxide-dependent activation of soluble guanylyl cyclase. J Clin Invest. 111(2):231-239.

6. Wong T, Brandow A, Lim W, Lottenberg R. (2014) Update on the use of hydroxyurea therapy in sickle cell disease. Blood. 124(26):3850-3857.

7. Imaga NA. (2013) Phytomedicines and nutraceuticals: alternative therapeutics for sickle cell anemia. Scientific World Journal. 269659.

8. Oyewole O, Malomo S, Adebayo J. (2008) Comparative studies on antisickling properties of thiocyanate, tellurite and hydroxyurea. Pak J Med Sci. 24(1):18-22.

9. Moody J, Ojo O, Omotade O, Adeyemo A, Olumese P, Ogundipe O. (2003) Anti-sickling potential of a Nigerian herbal formula (ajawaron HF) and the major plant component (Cissus populnea L. CPK). Phytother Res. 17(10):1173-1176.

10. Nwosu F, Dosumu O, Okocha J. (2008) The potential of Terminalia catappa (Almond) and Hyphaene thebaica (Dum palm) fruits as raw materials for livestock feed. Afr J Biotechnol. 7(24):4576-4580.

11. Imaga N, Gbenle G, Okochi V, Akanbi S, Edeoghon S, et al. (2009) Antisickling property of Carica papaya leaf extract. Afr J Biochem Res. 3(4):102-106.

12. Ekeke G, Shode F. (1985) The reversion of sickled cells by Cajanus cajan. Planta Med. 51(6):504-507.

13. Oduola T, Adeniyi F, Ogunyemi E, Bello I, Idowu T. (2006) Antisickling agent in an extract of unripe pawpaw (Carica papaya): is it real? Afr J Biotechnol. 5(20):1947-1949.

14. Mpiana P, Ngbolua K, Mudogo V, Tshibangu D, Atibu E, Tshilanda D, Misengabu N. (2011) Anti-sickle erythrocytes hemolysis properties and inhibitory effect of anthocyanins extracts of Trema orientalis (Ulmaceae) on the aggregation of human deoxyhemoglobin S in vitro. J Med Sci. 11 (3):129-137.

15. Alabdallat N, Adam I. (2016) In vitro antisickling activity of zingiber officinale roscoe (ginger) methanolic extract on sickle cell disease. British Journal of Medicine \& Medical Research. 12(12):1-7. 
16. World Health Organization Regional Committee for Africa. Sickle-cell disease: a strategy for the WHO African region. WHO: Malabo, Equatorial Guinea 2010; Pp;1-9.

17. Jastaniah W. (2011) Epidemiology of sickle cell disease in Saudi Arabia. Ann Saudi Med. 31(3):289-293.

18. Mbadiko C, Ngbolua K, Mpiana P, Hity M, Kikakedimau R, Makengo G. (2017) Phytochemical screening and assessment of anti-sickling activity of total methanol extracts of different organs of Curcuma longa L. (Zingiberaceae). The Pharmaceutical and Chemical Journal. 4(1):32-40.

19. Tshilanda D, Mutwale P, Onyamboko D, Babady P, Tsalu P. (2016) chemical fingerprint and anti-sickling activity of rosmarinic acid and methanolic extracts from three species Ocimum from DR Congo. Journal of Biosciences and Medicines. 4:59-68.

20. Mpiana P, Kitwa E, Kanangila A, Tshibangu D, Ngbolua K, Atibu E. (2009) Photodegradation on antisickling activity of anthocyanins extracted from a few Lubumbashi plants (DR Congo). Ann Fac Sci. 45-53.
21. Camatari F, Lopes K, Valentim B, Xavier J, Costa J, Santana A, Goulart M. (2016) Antioxidant potential of flours from cereals, tubers, beans and seeds. Chemical profile of Curcuma longa flour. Journal of Nutrition \& Food Sciences. 6(2), 483:1-8.

22. Kumar A, Singh M, Singh P, Singh S, Raj P, Pandy K. (2016) Antioxidant efficacy and curcumin content of turmeric (Curcuma-longa L.) flower. International Journal of Current Pharmaceutical Research. 8(3):112-114.

23. Yan S, Asmah R. (2010) Comparison of total phenolic contents and antioxidant activities of turmeric leaf, pandan leaf and torch ginger flower. International Food Research Journal. 17:417423.

24. Mbadiko C, Ngbolua K, Mpiana P, Ngombe N, Kapepula P, Kemfine L. (2019) Antioxidant potential and anti-sickling activity of different organs of Curcuma longa: correlation of the antioxidant capacity on anti-sickling activity. South Asian Reseach Journal of Natural Products. 2(2):1-16.
This work is licensed under Creative Commons Attribution 4.0 License
Ready to submit your research? Choose Auctores and benefit from:

* fast, convenient online submission

* rigorous peer review by experienced research in your field

* rapid publication on acceptance

* authors retain copyrights

* unique DOI for all articles

* immediate, unrestricted online access

At Auctores, research is always in progress.

Learn more www.auctoresonline.org/journals/clinical-medical-reviewsand-reports- 